\title{
The Mesoproterozoic 'seismite' at Laiyuan (Hebei Province, E China) re-interpreted
}

\author{
A.J. (Tom) Van Loon \\ Geological Institute, Adam Mickiewicz University, Maków Polnych 16, 61-606 Poznań, Poland; \\ email: tvanloon@amu.edu.pl; tom.van.loon@wxs.nl
}

\begin{abstract}
A 1-million $\mathrm{m}^{3}$ breccia near Laiyuan (Hebei Province, E China) occurs as a block-like lithological unit between dolostones of the 1.55-1.45 Ga (Early Mesoproterozoic) Wumishan Formation. It has previously been interpreted as a seismite, but it appears not to fulfil any of the commonly accepted criteria that jointly are considered diagnostic for seismites. Its presence in a graben-like structure with almost vertical bounding fault planes rather indicates an origin as a (submarine) valley fill. As the valley originated by tectonic activity in the form of faulting, the breccia can be considered as a secondary effect of seismic activity, but it does not represent a seismite.
\end{abstract}

Keywords: seismite, valley fill, graben sedimentation, Wumishan Formation, Mesoproterozoic, Fangshan geopark, Hebei Province, China

\section{Introduction}

The breccia under study is situated some $190 \mathrm{~km}$ SW of Beijing, in Laiyuan County, Hebei Province, E China (Fig. 1). It is located in the Baishishan recreational area, which now forms part of the Fangshan Geopark. The breccia has been described thoroughly by Liang et al. (2002a), who interpreted the breccia body as a seismite, the oldest mentioned from China. Their descriptions raised some questions about the origin of the breccia body, however, which resulted in a new analysis based on fieldwork carried out in 2013 to assess their conclusions, with the objective to reconstruct more precisely the genesis of the breccia.

\section{Geological setting}

The breccia forms part of the Wumishan Formation, which developed on the Yan-Liao aulacogen (in the northern part of the Sino-Korean palaeo-plate; North China Craton). This is a vast area where sediments accumulated during the Mesoand Neoproterozoic, building up successions of up to $9200 \mathrm{~m}$ thick (He et al., 2000; Qiao \& Gao, 2007). The thickest succession is found in the centre of the aulacogen. This area can be considered as part of a rift system where the Columbia supercontinent started breaking up between 1.6 and $1.2 \mathrm{Ga}$ ago (Rogers \& Santosh, 2002; Qiao et al., 2007). This break-up was accompanied by earthquakes that resulted in seismic shocks that triggered soft-sediment deformation (Qiao et al., 2007; Ettensohn et al., 2011). The resulting structural elements are prominent: they were possibly reactivated even much later, when folding and faulting occurred in the Beijing area during the Late Jurassic-Early Cretaceous.

The Meso-Neoproterozoic rocks on the aulacogen are now grouped into twelve formations that jointly are up to $9200 \mathrm{~m}$ thick (Van Loon \& Su, 2013): from bottom to top the Mesoproterozoic Changzhougou, Chuanlinggou, Tuanshanzi, Dahongyu, Gaoyuzhuang, Yangzhuang, Wumishan, Hongshuizhuang, Tieling, and Xiamaling Formations, which 


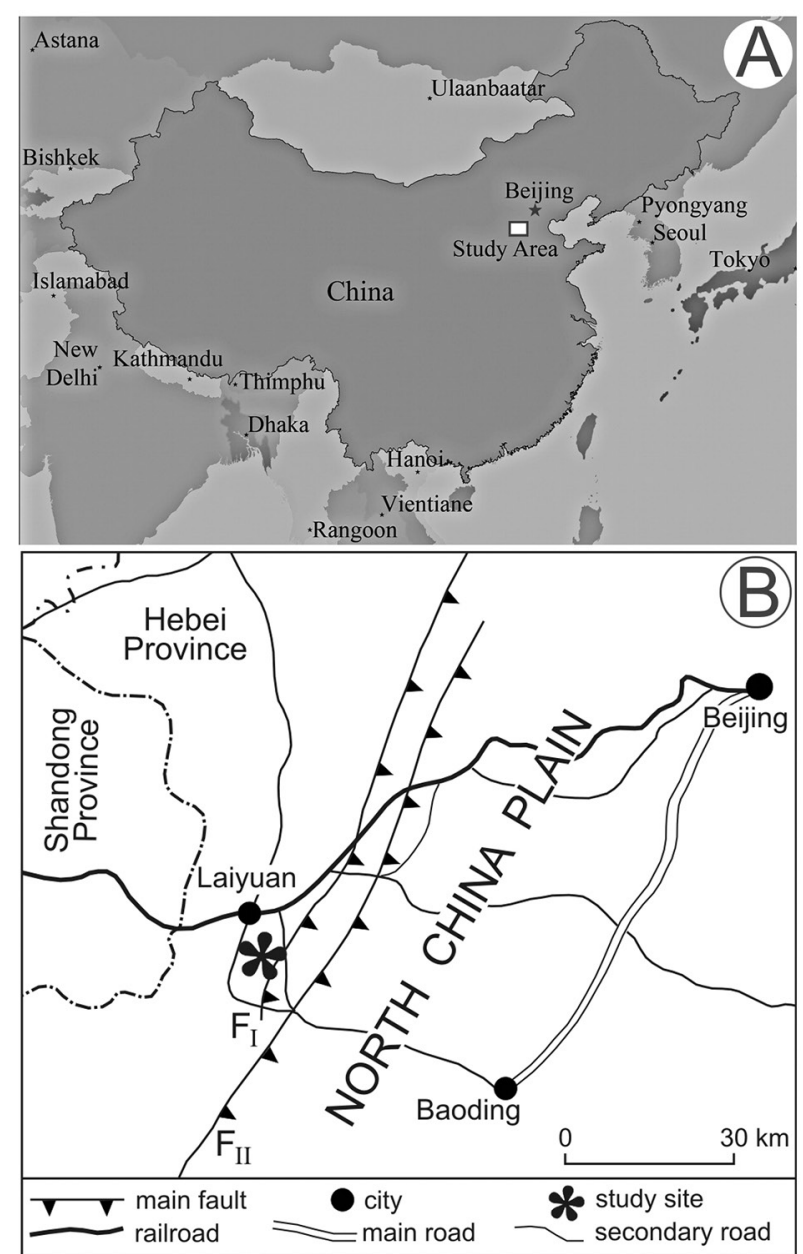

Fig. 1. Location of the study site.

A: Location within China; B: Location near Laiyuan (modified after Liang et al., 2002a).

are overlain by the Neoproterozoic Longshan and Jingeryu Formations. The Neoproterozoic is unconformably overlain by limestones of Cambrian age. The ages of the various formations have been well established in the past few decades. The Wumishan Formation, to which the breccia described below belongs, has been dated - on the basis of SHRIMP $\mathrm{U}-\mathrm{Pb}$ zircon ages - as between 1550 and $1450 \mathrm{Ma}$ (Gao et al., 2007; Li et al., 2010; Su et al., 2008, 2010), i.e. Early Mesoproterozoic; when Liang et al. (2002a) described the breccia, they still held to an age of the Wumishan Formation of 1.4-1.0 Ga.

\section{The Wumishan Formation}

The Wumishan Formation is the most widely distributed stratigraphic unit in the Beijing area, forming about $12 \%$ of the outcropping rocks. The formation consists for $89 \%$ of carbonate rocks (Su \& Sun, 2012), almost exclusively dolomites; de re- mainder consists of silicified carbonate rocks (10\%) and siliciclastic rocks (1\%). Locally the dolomites have turned into marble (in which seismically deformed stromatolites are visible: Van Loon \& Su, 2013), indicating synsedimentary seismic activity. Su \& Sun (2012) calculated the occurrence of earthquakes with sufficient magnitude to produce soft-sediment deformation structures as once per 20,000-32,000 years.

The Wumishan Formation has been investigated - and is still being investigated - by numerous researchers (e.g. Wang et al., 1995; Mei et al., 2001; Zhang et al., 2007; Liang et al., 2009; Su \& Sun, 2011; Su et al., 2013; Van Loon \& Su, 2013). The formation is about a kilometre thick in the study area and is largely composed of stacked peritidal parasequences (each a few to some dozens of metres thick), separated by silty shales. These parasequences contain subtidal high-energy cross-bedded dolarenites at the base, which are gradually overlain by lagoonal dolosiltites and low peritidal laminites with mudcracks in the upper part of a parasequence.

On the basis of the stacking pattern, the rock composition and the stromatolite characteristics, the Wumishan Fm. is subdivided into four members; the breccia under study forms part of the one but oldest member, which is a few hundreds of metres thick; it shows a wide variation in rock types, from quartz sandstone to sandy dolostone, laminated dolostone, siliceous dolostone (Fig. 2), stromatolitic dolostone (Fig. 3) and bituminous dolostone, reflecting changes in the palaeo-environment. These changes in the environment involved mainly fluctuations of the water depth, but the entire development of the Wumishan Formation took place in a shallow-marine (shelf) to intertidal environment (cf. Song \& Gao, 1985; Ruiji, 1991) where the conditions were mostly very quiet, apart from the tidally influenced environments. Also the commonly quiet environments underwent disturbanc-

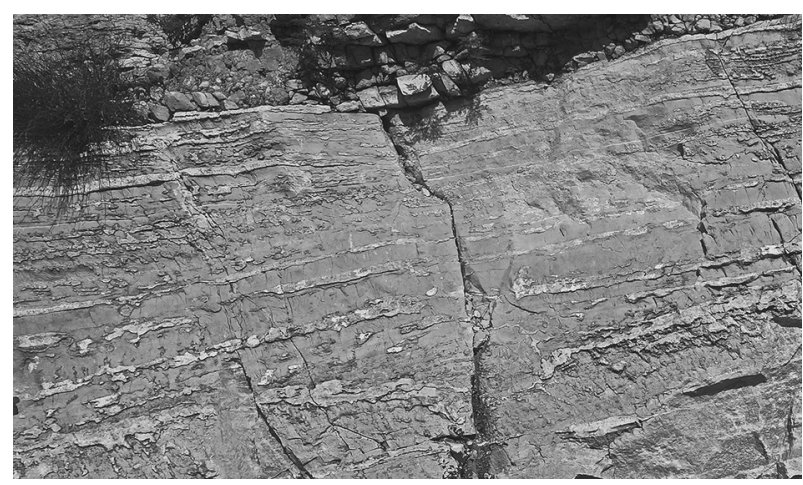

Fig. 2. The siliceous dolostone from the second member of the Wumishan Formation in the Baishishan recreational area. 


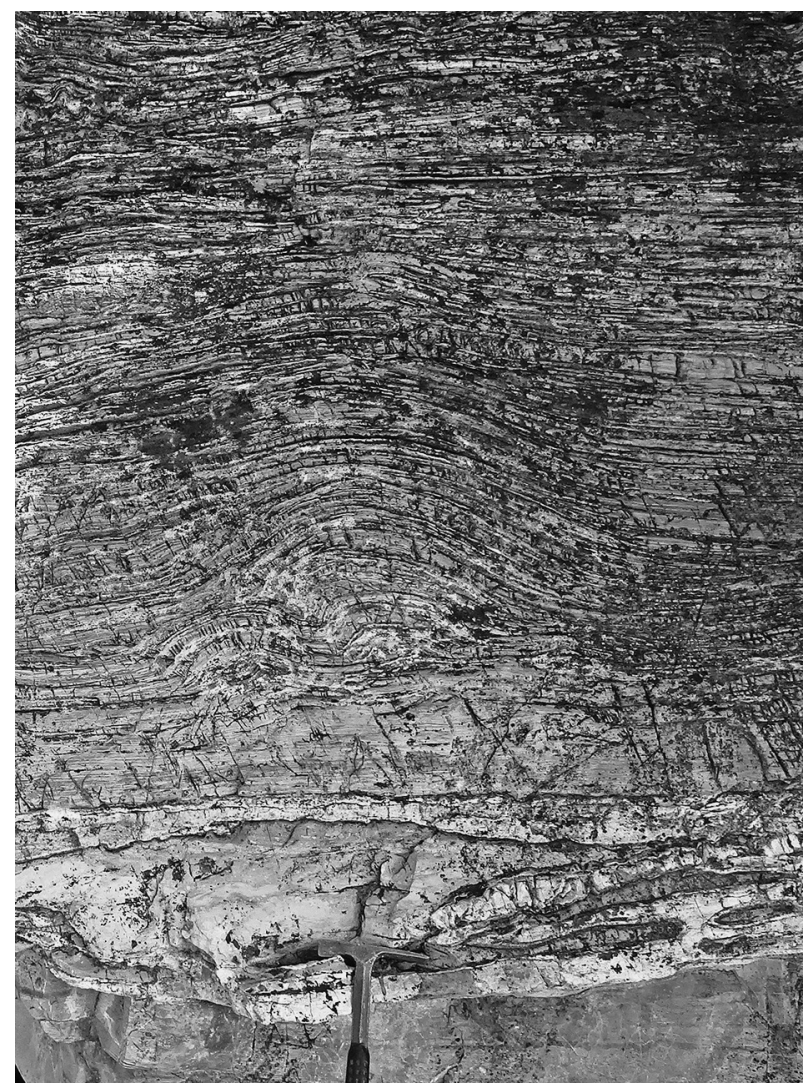

Fig. 3. Stromatolite development in the second member of the Wumishan Formation in the Baishishan recreational area.

es, however, due to storms, but particularly by the seismic activity that affected many of the Meso- and Neoproterozoic formations (e.g. Liu, 2001; Duan et al, 2002; Liang et al., 2002b; Qiao \& Gao, 2007; Qiao et al., 2007); these earthquakes also disturbed the Meso- to Neoproterozoic succession by triggering tsunamis (e.g. Song et al., 1988; Liang et al., 2009; Ettensohn et al., 2011).

\section{Description of the breccia}

The breccia, the contact of which with the surrounding dolostones can be studied only locally because of vegetation and exposure at high levels in vertical walls, forms a large body of some 500 $\mathrm{m}$ long, $300 \mathrm{~m}$ wide and probably of the order of some $60 \mathrm{~m}$ thick (the contacts with the overlying and underlying dolostones are not accessible), thus constituting a volume of the order of a million cubic metres. For this reason Liang et al. (2002a) called it a megabreccia (without defining the difference with a 'normal' breccia). The original volume can even have been considerably larger than a million cubic metres, as a valley exists in front of the breccia body where the breccia may have had a continuation: the orientation of the valley is NNE-SSW, just like that of the breccia body. Morphologically, it is even likely that the valley represents now a continuation of the depression in which the breccia is present, but where the breccia has been eroded away.

The breccia is embedded in the dolostones mentioned above. The clasts of the breccia consist of the same types of dolostone, including limestone fragments with stromatolites. The clasts do not show any preferred orientation and are extremely poorly sorted (Fig. 4). Whereas a majority of the clasts is only a few decimetres long, there are also huge blocks of several metres; Liang et al. (2002a) mention even blocks of over $10 \mathrm{~m}$. Most of the clasts are

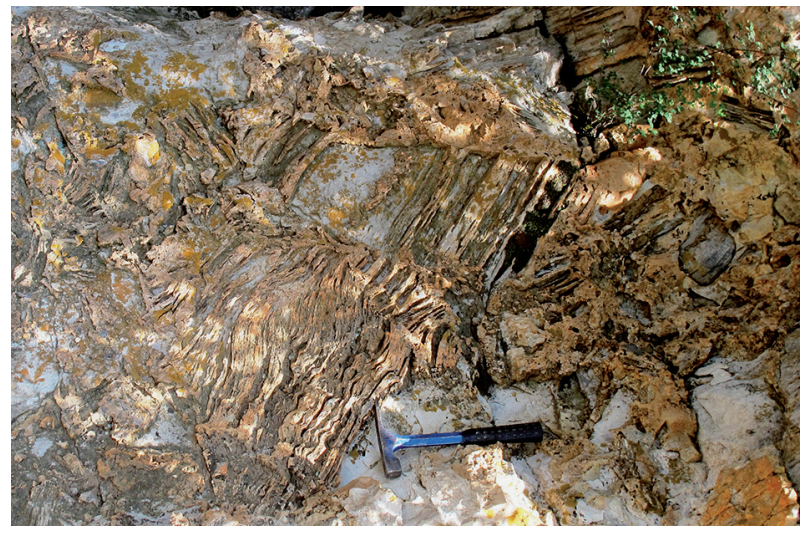

Fig. 4. The poorly sorted character of the breccia without any preferred orientation.

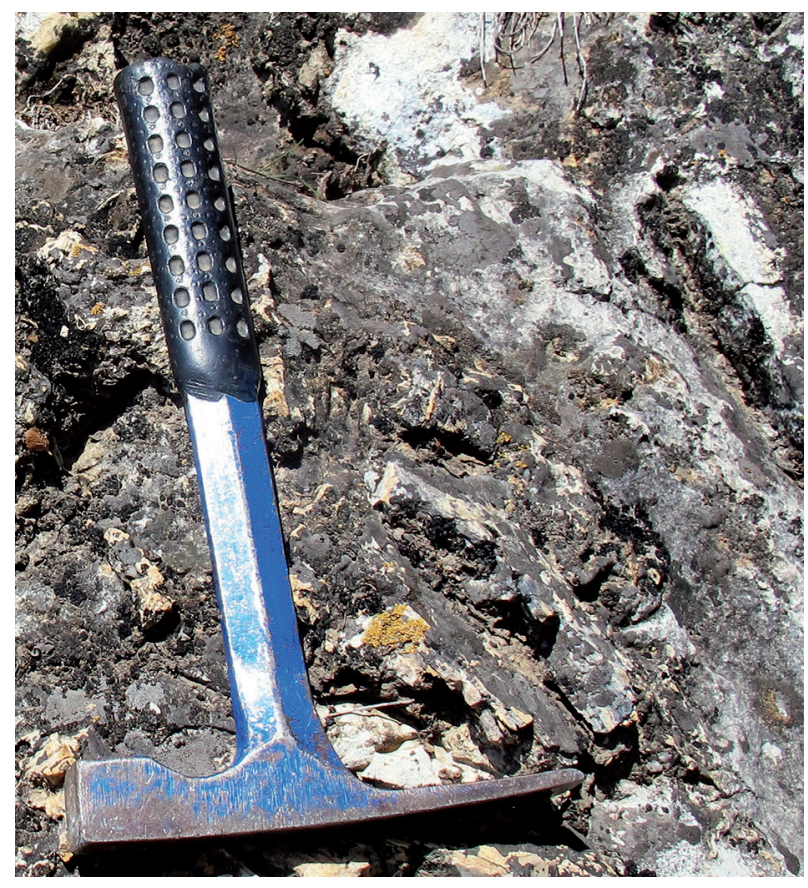

Fig. 5. Contacts between clasts and between clasts and matrix are obscured by recrystallization. 
angular, but some clasts show a certain degree of rounding (they are maximally subrounded), which must be ascribed to either the brecciation process or some process after emplacement. The matrix, which is now commonly present as a cement, consists of the same material as the clasts. Liang et al. (2002a) mention a gradual boundary between clasts and matrix/cement, but only sharp contacts were found during the present study, though often obscured by recrystallisation that took place after deposition of the clasts (Fig. 5).

No clear layering is visible in the breccia, but it appears that irregular patches or zones occur that are characterised by a smaller or larger average particle size than the adjacent material, or by material that is somewhat less or somewhat more rounded than the adjacent material. This feature resembles in many respects that of pebbly mudstones that were deposited by debris flows in a syntectonic depositional flysch-like environment (cf. Van Loon, 1972).

\subsection{Boundaries of the breccia}

The breccia is bounded at both sides by large normal faults, which start and stop in the second member of the Wumishan Formation, suggesting that they are synsedimentary. Some synthetic and a few antithetic faults are also present. All these faults strike NNE-SSW, but they have different dip directions: they are all (apart from the antithetic faults) normal faults slightly dipping towards each other, thus forming a graben-like structure. Liang et al. (2002a; their fig. 2) showed these faults to have a dip of some $75^{\circ}$, but the faults actually are almost vertical, dipping exceptionally steeply, namely some $80-90^{\circ}$ (Fig. 6). The depth of the graben structure is locally of the order of $50-75 \mathrm{~m}$, but cannot be traced throughout the graben.

It is remarkable that Liang et al. (2002a) show, in their figure 2, also a much smaller graben, but they do not devote any text to this feature, and it could not be traced in the field during the present study. For the time being, and without further details from the 2002 authors, this second graben should be considered as a hypothetical one, based on the experience that numerous grabens are accompanied by smaller, secondary grabens, though usually as secondary grabens at the bottom of the main graben like, for instance in the Kleszczów Graben (central Poland) (Gotowała \& Hałuszczak, 2002). It is interesting that in this latter graben also numerous seismites, seismically induced breccias and other soft-sediment deformation structures are present

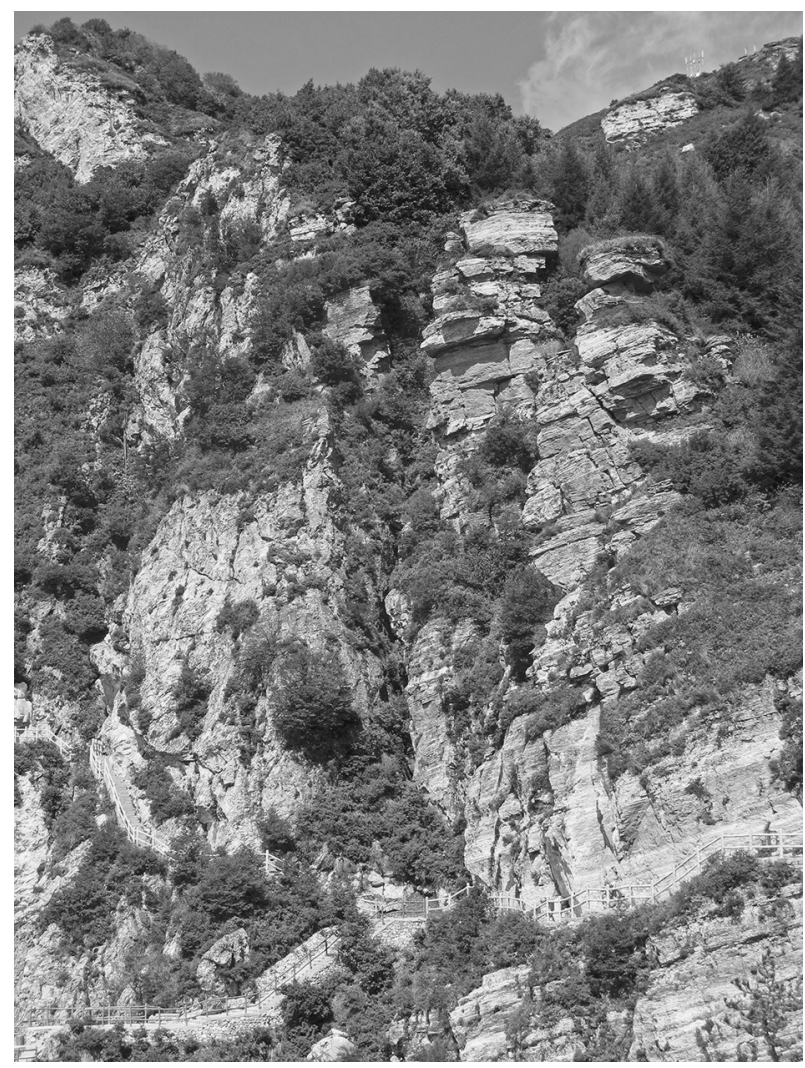

Fig. 6. Almost vertical fault between the undeformed dolostone (right) and the breccia (left).

(e.g. Brodzikowski et al., 1987; Van Loon et al., 1995; Van Loon, 2002; Gruszka \& Van Loon, 2007).

\section{Discussion of the breccia's genesis}

The breccia was called a 'megaseismite' by Liang et al. (2002a), without giving details why it should be a seismite. Possibly they regarded the relationship with active faulting as sufficient, which would imply that that they misunderstood what a seismite is. This seems the most logical explanation, as the diagnostic features of a seismite are, as detailed below, lacking. This leaves the question of what actually was the genesis of the brecciated graben infilling.

\subsection{Lack of characteristics of a seismite}

Considering the occurrence of the breccia as a lithological body that fills a structure that can be interpreted only as a graben, and considering that the lithology of the breccia clasts is identical to that of the surrounding rocks, it is beyond reasonable doubt that the breccia is related to the fault activity that resulted in the graben, the more so since the 
vertical extent of the graben-bordering faults indicates syndepositional fault activity. The breccia can, however, not be considered as a seismite; not only because it does not fulfil any of the 'diagnostic' criteria (Sims, 1973, 1975; Owen \& Moretti, 2011), even taking into account that these 'diagnostic' criteria should be handled with much caution (Moretti \& Van Loon, 2014), but particularly because a seismite results from the deformations caused by the passing of an S-wave (cf. Van Loon \& Pisarska-Jamroży, 2014), which commonly affects only the uppermost few decimetres of sediment, in exceptional cases a metre or somewhat more, which can result in 'giant' seismites (Alfaro et al., 2010). No such deformations are present in the sediments under study, however, although they are common in seismites (see, for instance, He, 2014; Perruca et al., 2014; Sarkar et al., 2014, Valente et al., 2014, Uner, 2014; all in this issue).

It should be kept in mind, however, that Liang et al. (2002a) apparently used the term 'seismite' not in the sense in which Seilacher $(1969,1984)$ introduced it, viz. as a layer with earthquake-induced (most commonly soft-sediment) deformation structures (see Van Loon, 2014, this issue), but rather as a sediment that originated due to earthquake activity.

If one considers a breccia composed of lithified clasts potentially a seismite (and there exist numerous examples where at least consolidated and sometimes partly lithified surficial sediments became brecciated by a seismic shock (Gruszka \& Van Loon, 2007), it should be realised that this cannot be the case here. If seismic shocks, affecting the topmost (already lithified) carbonates of even a metre thick, there should have been at least some 50 seismic shocks affecting the sediment in order to form a breccia unit of $50 \mathrm{~m}$ thick. In the case of so many earthquakes with magnitudes that could result in brecciation of lithified material, also the sediments outside the graben would have been affected, however, but there are no signs of such brecciation or other deformation. It must thus be concluded that the breccia infilling of the graben was not caused by a series of successive seismic shocks; only the faulting resulting in the formation of the graben must, evidently, have been accompanied by seismic shocks, but these have not been found to have left any observable traces in the sedimentary record outside the graben.

\subsection{An alternative genetic interpretation}

The dolostone succession in which the breccia-containing graben is embedded, consisted still of limestones when the brecciation took place. It forms a succession without any apparent interruptions, and the same type of succession (of what are now dolostones of various types) is present on top of the breccia. This implies that the graben structure must eventually have been filled up partly or completely with breccia clasts. It also implies, considering the graben structure, that the breccia forms some kind of 'additional' sediment, filling up the elongated depression resulting from the graben formation.

The dolostone succession in the study area represents quiet conditions, without any supply of coarse clastics, and the shallow-marine environment favoured the development of stromatolites. These environmental conditions hold for both the dolostones outside the graben and the sediments under- and overlying the breccia. The fine lamination in the dolostones and the almost complete lack of current ripples indicate that bottom currents were rare; where present, the small size of the ripples indicate fairly insignificant currents. It is consequently unrealistic to assume that extremely coarse clastic material (including metre-sized blocks) was supplied from some remote source area to fill up the graben; moreover, the breccia clasts consist of the same material as the dolostones alongside the graben. It must therefore be deduced that the breccia clasts are autochthonous. The question thus arises where in the direct neighbourhood - and how - the breccia clasts with sometimes extraordinary large sizes could develop.

The local topographic situation is the clue: during the formation of the graben a depression with almost vertical walls was formed in the otherwise quiet depositional environment. It is in this context irrelevant whether a deep depression was formed during a single faulting phase, or whether this occurred during a number of successive steps (which seems more likely). Whatever was the case, a kind of elongated depression with (almost) vertical walls originated, possibly in a staircase-like configuration due to the development to synthetic faults. The almost vertical walls must have represented an unstable situation, particularly because the sedimentary surface was no longer horizontal, but showed inclinations. Where the subaqueous walls of the graben were more or less vertical, blocks may have tumbled down as some kind of 'rain' (but at a geological depositional rate) because the faulting must have resulted in a fault zone with fragmented material. Large blocks thus fell from the steep walls, together with - and taking along - finer material that was become to act as the matrix (later cement) of the breccia inside the graben (Fig. 7). Where the sedi- 

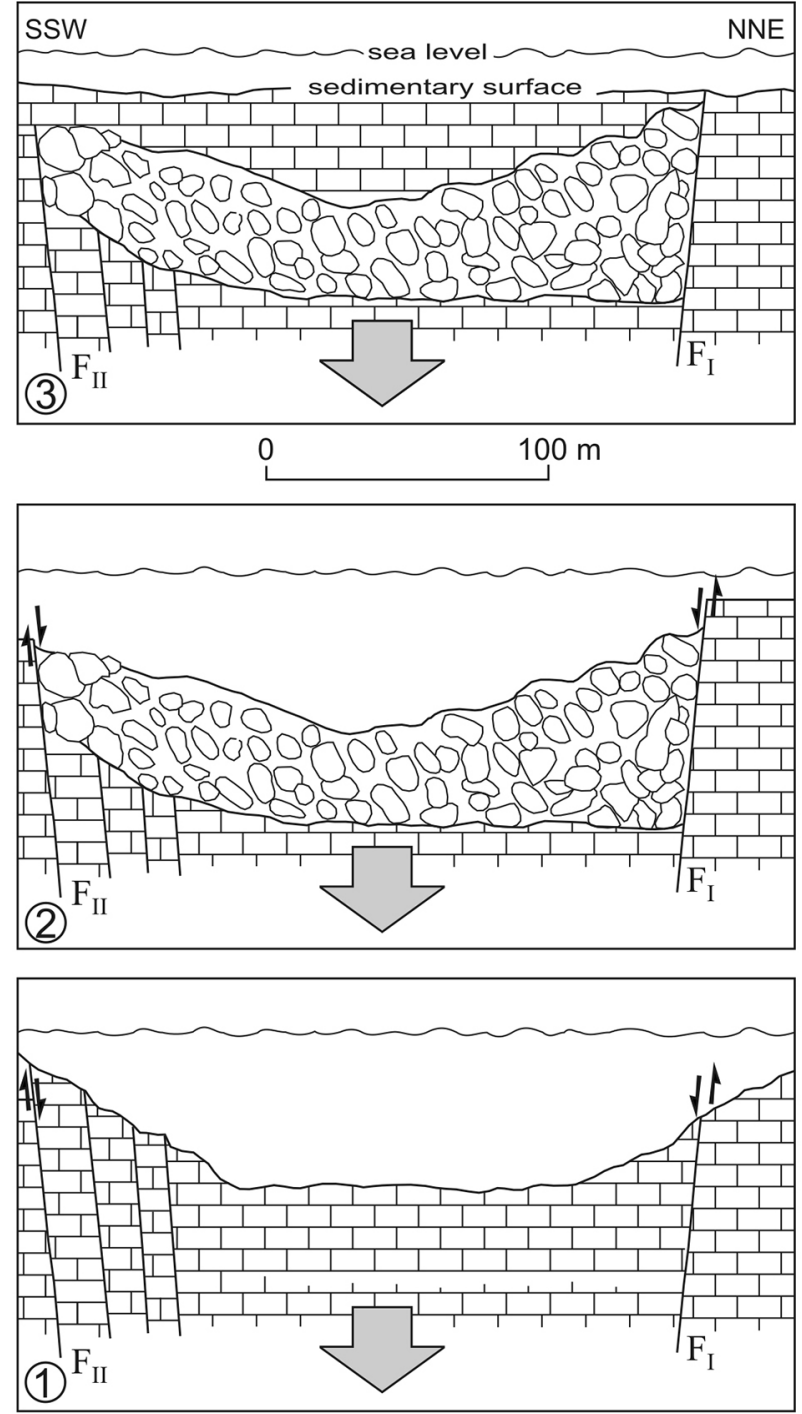

Fig. 7. Model for the gradual infilling of the graben by material tumbled down from the almost vertical graben walls (adapted from Liang et al., 2002a).

mentary surface was less steeply inclined, the fragmented material must have moved downwards in the form of slumps and mudflows. Although such deposits cannot be clearly distinguished in the breccia under study, it is most likely that the majority of the breccia consists of mass-transported material, as there are zones with different characteristics (main size, rounding). It is interesting in this context that several graben-related breccias with some similar aspects are known, for instance the Neoproterozoic St. Regis Breccia in Idaho (Anderson, 1967) and the Late Oligocene Llano Quemado Breccia in New Mexico (McDonald \& Nielsen, 2004), but these breccias are much smaller than the breccia under study.

The fact that, as well known from modern carbonate environments (Shinn, 2013) and also from ancient deposits (Van Loon et al., 2013), lithification of limestones does not take place regularly with increased depositional depth, explains why lithified levels - supplying the rigid clasts - co-occurred with consolidated but still unlithified carbonates, represented now as clasts with rounded edges.

\section{Problems regarding recognition of a seismite}

Seismites are special in that they represent sediments that have been affected and deformed by seismic shocks at or near the sedimentary surface. Recognition is often difficult because the conditions to study them do not always allow to test whether they meet the 'diagnostic' criteria that have become commonly accepted in the past forty years (Sims, 1973 , 1975). As a result, probably numerous deformed layers ranging in age from the Proterozoic to modern times which may well represent seismites, will not yet have been recognised as such. On the other hand, it also appears that several layers in the sedimentary record of the Earth have been interpreted as seismites (with implications for the tectonic history of the area under study), while later investigations resulted in arguments that exclude an origin as seismite. The breccia at Laiyuan is an example of the latter.

It is worthwhile to mention, however, that failure to recognise a seismite, as well as the incorrect interpretation of a layer as a seismite does not imply research of insufficient quality: the conditions for a correct analysis may have been absent or the knowledge of seismites may have been insufficient at the time. Most important, however, is that accurate descriptions of the various features are provided. This certainly was the case in the work by Liang et al. (2002a), whose descriptions were so detailed that they attracted attention, resulting in a new field study that - with the present-day knowledge of seismites - came to a different conclusion. But that only is how science proceeds.

\section{Conclusions}

The large breccia body at Laiyuan (Hebei Province, E China) fills an elongated depression that was caused by graben formation. The depression became filled with clasts and matrix that originated and tumbled down from the (almost) vertical graben walls or flowed down by mass transport from inclined surfaces, possibly triggered by earthquakes. As a result, the infilling of the graben consists of 
particles (ranging from silt size to large boulders) that have the same composition as the sediments alongside the graben. This infilling thus represents typical graben sedimentation, in the form of a submarine valley fill, and does not represent a seismite.

\section{Acknowledgements}

The author gratefully acknowledges the financial support by the organisers and sponsors of the $1^{\text {st }}$ International Palaeogeographical Conference at Beijing (September 2013), which allowed the author to carry out the fieldwork for this study. Dr Su Dechen (Beijing) kindly translated the Chinese text of Liang et al. (2002a) into English, and arranged transport to the study area. I thank Prof. Tomasz Zieliński (AMU, Poznań) for drawing Figures $1-B$ and 7.

\section{References}

Alfaro, P., Gibert, L., Moretti, M., García-Tortosa, F.J., Sanz de Galdeano, C., Jesús Galindo-Zaldívar, J. \& López-Garrido, A.C., 2010. The significance of giant seismites in the Plio-Pleistocene Baza palaeo-lake (S Spain). Terra Nova 22, 172-179.

Anderson, R.A., 1967. Graben structure in the Coeur d'Alene district, Idaho. Economic Geology 62, 10921094.

Brodzikowski, K., Gotowala, R., Kasza, L. \& Van Loon, A.J., 1987. The Kleszczów Graben (central Poland): reconstruction of the deformational history and inventory of the resulting soft-sediment deformational structures. [In:] M.E. Jones \& R.M.F. Preston (Eds): Deformation of sediments and sedimentary rocks. Geological Society, London, Special Publication 29, 241-254.

Duan, J., Liu, P. \& Wan, C., 2002. Mesoproterozoic and Neoproterozoic seismite and its rhythm in the Yanshan area, North China Platform. Acta Geologica Sinica 76, 441-445 (in Chinese with English abstract).

Ettensohn, F.R., Zhang, C. \& Lierman, R., 2011. Soft-sediment deformation in epicontinental carbonates as evidence of paleoseismicity with evidence for a possible new seismogenic indicator: accordean folds. Sedimentary Geology 235, 222-233.

Gao, L.Z., Zhang, C.H., Shi, X.Y., Zhou, H.R., Wang, Z.Q. \& Song, B., 2007. A new SHRIMP age of the Xiamaling Formation in the North China Plate and its geological significance. Acta Geologica Sinica 81, 1103-1109.

Gotowała, R. \& Hałusczak, A., 2002. The Late Alpine structural development of the Kleszczów Graben (central Poland) as a result of reactivation of the pre-existing, regional dislocations. EGU Stephan Mueller Special Publication Series 1, 137-150.

Gruszka, B. \& Van Loon, A.J., 2007. Earthquake-induced glaciolacustrine breccias in the Belchatow mine (central Poland). Sedimentary Geology 193, 93-104.

He, Z., Song, T., Ding, X., Zhang, Q., Meng, X. \& Ge, M., 2000. The early synsedimentary faulting of the Me-
so-Proterozoic Yanshan rift and its influence on event sedimentation. Journal of Palaeogeography 2, 83-91 (in Chinese with English abstract).

He, B., Qiao, X., Jiao, C., Xu, Z., Cai, Z., Guo, X., Zhang, Y. \& Zhang, M., 2014. Paleo-earthquake events in the late Early Palaeozoic of the central Tarim Basin: evidence from deep drilling cores. Geologos 20, 105-123.

Li, H.K., Zhu, S.X., Xiang, Z.Q., Su, W.B., Lu, S.N., Zhou, H.Y., Geng, J.Z., Li, S. \& Yang, F.J., 2010. Zircon U-Pb dating on tuff bed from Gaoyuzhang Formation in Yanquing, Beijing: further constraints on the new subdivision of the Mesoproterozoic stratigraphy in the North China Platform. Acta Petrologica Sinica 26, 2131-2140.

Liang, D.Y., Song, Z.M. \& Nie, Z.T., 2002a. Seismites in the Middle Proterozoic at Baishushan, Hebei Province. Geological Bulletin of China 21, 625-628 (in Chinese).

Liang, D.Y., Song, Z.M., Zhao, C.H. \& Nie, Z.T., 2002 b. Discovery of Mesoproterozoic seismites at Baishi Mountain, Hebei Province and its geological significance. Geological Bulletin of China 21, 625-630.

Liang, D., Nie, Z., Song, Z., Zhao, C, Chen, K. \& Gong, H., 2009. Seismic-tsunami sequence and its geological features of Mesoproterozoic Wumishan Formation in Fangshan Global Geopark, Beijing, China: a case study on Yesanpo scenic district. Geological Bulletin of China 28, 30-37 (in Chinese with English abstract).

Liu, P., 2001. Seismite and its rhythm in the Gaoyuzhang Formation of Mesoproterozoic in Pingquan County, Hebei Province. Geoscience 15, 266-268 (in Chinese with English abstract).

McDonald, D.W. \& Nielsen, K.C., 2004. Structural and stratigraphic development of the Miranda Graben constrains the uplift of the Picuris Mountains. New Mexico Geological Society Field Guidebook 55, 219-229.

Mei, M., Ma, Y. \& Guo, Q., 2001. The basic model of Wumishan cyclothems and their Markov chain analysis, Jixian section of Tianjin. Geological Journal of Chinese Universities 7, 288-299 (in Chinese with English abstract).

Moretti, M. \& Van Loon, A.J., 2014. Restrictions to the application of 'diagnostic' criteria for recognizing ancient seismites. Journal of Palaeogeography 3, 162-173.

Owen, G. \& Moretti, M., 2011. Identifying triggers for liquefaction-induced soft-sediment deformation in sands. Sedimentary Geology 235, 141-147.

Perucca, L.P., Godoy, E. \& Pantano, A., 2014. Late Pleistocene-Holocene earthquake-induced slumps and soft-sediment deformation structures in the Acequion River valley, Central Precordillera, Argentina. Geologos 20, 147-156.

Qiao, X. \& Gao, L., 2007. Mesoproterozoic earthquake and palaeogeography in Yan-Liao Aulacogen. Journal of Palaeogeography 9, 337-352 (in Chinese with English abstract).

Qiao, X., Gao, L. \& Peng, Y., 2007. Mesoproterozoic earthquake event and breakup of the Sino-Korean Plate. Acta Geologica Sinica 81, 385-397. 
Rogers, J.J.W. \& Santosh, M., 2002. Configuration of Columbia, a Mesoproterozoic supercontinent. Gondwana Research 5, 5-22.

Ruiji, C., 1991. Origin and order of cyclic growth patterns in mat ministromatolite bioherms from the Proterozoic Wumishan formation, North China. Precambrian Research 52, 167-178.

Sarkar, S., Choudhuri, A., Banerjee, S., Van Loon, A.J. \& Bose, P.K., 2014. Seismic and non-seismic soft-sediment deformation structures in the Proterozoic Bhander Limestone, central India. Geologos 20, 89-103.

Seilacher, A., 1969. Fault-graded beds interpreted as seismites. Sedimentology 13, 15-159.

Seilacher, A., 1984. Sedimentary structures tentatively attributed to seismic events. Marine Geology 55, 1-12.

Shinn, G., 2013. Bootstrap geologist - my life in science. University Press of Florida (Gainesville), 298 pp.

Sims, J.D., 1973. Earthquake-induced structures in sediments of Van Norman Lake, San Fernando, California. Science 182, 161-163.

Sims, J.D., 1975. Determining earthquake recurrence intervals from deformational structures in young lacustrine sediments. Tectonophysics 29, 141-152.

Song, T. \& Gao, J., 1985. Tidal sedimentary structures from Upper Precambrian rocks of the Ming Tombs District, Beijing (Peking), China. Precambrian Research 29, 93-107.

Song, T.R., 1988. A probable earthquake-tsunami sequence in Precambrian carbonate strata of Ming Tombs District, Beijing. Chinese Science Bulletin 33, 1121-1124.

Su, D. \& Sun, A., 2011. Soft-sediment deformation and occurrence frequency of palaeoearthquake in the Mesoproterozoic Wumishan Formation, Yongding River valley, Beijing. Journal of Palaeogeography 13, 591-614 (in Chinese with English abstract).

Su, D. \& Sun, A., 2012. Typical earthquake-induced soft-sediment deformation structures in the Mesoproterozoic Wumishan Formation, Yongding River valley, Beijing, China and interpreted earthquake frequency. Journal of Palaeogeography 1, 71-89.

Su, D., Qiao, X., Sun, A., Li, H. \& Somerville, I.D., 2013. Large earthquake-triggered liquefaction mounds and a carbonate sand volcano in the Mesoproterozoic Wumishan Formation, Beijing, North China. Geological Journal, doi: 10.10021/gj.2501, 21 pp.

Su, W.B., Zhang, S.H., Huff, W.D., Li, H.K., Ettensohn, F.R., Chen, X.Y., Yang, H.M., Han, Y.G., Song, B. \& Santosh, M., 2008. SHRIMP U-Pb ages of K-bentonite beds in the Xiamaling Formation: Implications for revised subdivision of the Meso- to Neoproterozoic history of the North China Craton. Gondwana Research 14, 543-553.
Su, W.B., Li, H.K., Huff, W.D., Ettensohn, F.R., Zhang, S.H., Zhou, H.Y. \& Wan, Y.S., 2010. SHRIMP U-Pb dating for a K-bentonite bed in the Tieling Formation, North China. Chinese Science Bulletin 55, 3312-3323.

Üner, S., 2014. Seismogenic structures in Quaternary lacustrine deposits of Lake Van (eastern Turkey). Geologos 20, 79-87.

Valente, A., Ślącka, A. \& Cavuoto, G., 2014. Soft-sediment deformation in Miocene deep-sea clastic deposits (Cilento, southern Italy). Geologos 20, 67-78.

Van Loon, A.J., 1972. A prograding deltaic complex in the Upper Carboniferous of the Cantabrian Mountains (Spain): the Prioro-Tejerina Basin. Leidse Geologische Mededelingen 48, 1-81.

Van Loon, A.J., 2002. Soft-sediment deformations in the Kleszczów Graben (central Poland). [In:] P.K. Bose, S. Sarkar \& P.G. Ericksson (Eds): Rift basins: sedimentology and palaeontology - Chanda Memorial Issue. Sedimentary Geology 147, 57-70.

Van Loon, A.J., 2014. The life cycle of seismite research. Geologos 20, 61-66.

Van Loon, A.J. \& Pisarska-Jamroży, M., 2014. Sedimentological evidence of Pleistocene earthquakes in NW Poland induced by glacio-isostatic rebound. Sedimentary Geology 300, 1-10.

Van Loon, A.J. \& Su, D., 2013. Deformed stromatolites in marbles of the Mesoproterozoic Wumishan Formation as evidence for synsedimentary seismic activity. Journal of Palaeogeography 2, 390-401.

Van Loon, A.J., Brodzikowski, K. \& Zielinski, T., 1995. Shock-induced resuspension deposits from a Pleistocene proglacial lake (Kleszczów Graben, central Poland). Journal of Sedimentary Research A65, 417-422.

Van Loon, A.J., Han, Z. \& Han, Y., 2013. Origin of vertically oriented clasts in brecciated shallow-marine limestones of the Chaomidian Formation (Furongian, Shandong Province, China). Sedimentology 60, 1059_ 1070.

Wang, S., Sang, H., Qiu, J., Chen, M. \& Li, M., 1995. The forming ages of Yangzhuang and Wumishan Formations in Jixian section, northern China. Scientia Geologica Sinica 30, 166-173 (in Chinese with English abstract).

Zhang, C., Wu, Z., Gao, L., Wang, W., Tian, Y. \& Ma, C., 2007. Earthquake-induced soft-sediment deformation structures in the Mesoproterozoic Wumishan Formation, North China, and their geological implications. Science in China D 50, 350-358.

Manuscript submitted 9 December 2013 Revision accepted 24 December 2013 